\title{
THE EFFECT OF INHALATION OF NEBULIZED STEROID ON THE ACID ASPIRATION SYNDROME
}

\author{
C. Brian Warriner, Louise Brooks and Peter D. Pare
}

\begin{abstract}
The effects of acid aspiration on lung mechanics, gas exchange, haemodynamics and lung water, and their modification by nebulized dexamethasone were studied in 10 dogs. Each dog received $0.1 \mathrm{~N} \mathrm{HCl} \mathrm{pH}$ of $1.0(15 \mathrm{ml} / \mathrm{l}$ vital capacity), instilled down the tracheal tube. PEEP $0.98 \mathrm{kPa}\left(10 \mathrm{~cm} \mathrm{H}_{2} \mathrm{O}\right)$ was introduced 20 minutes after aspiration and was continued until the completion of experiment. Treated animals $(\mathrm{N}=5)$ received dexamethasone $5 \mathrm{mg} \cdot \mathrm{kg}^{-1}$ by continuous nebulization over a two hour period starting 20 minutes after aspiration. Untreated $(\mathrm{N}=5)$ animals received nebulized saline. Measurements were taken before aspiration and at 20 minutes 2.5 and 5.0 hours after aspiration. Red blood cells labelled with ${ }^{51} \mathrm{Cr}$ were injected before sacrifice. After sacrifice multiple lung samples were taken for measurement of pulmonary extravascular water (PEW) by the gravimetric technique. Acid aspiration caused significant changes in lung volumes, $\mathrm{Pa}_{0_{2}}$, and intrapulmonary shunt. Pulmonary extravas cular water was $6.16 \pm 0.93 \mathrm{ml} / \mathrm{g}$ dry tissue in treated and $6.47 \pm 0.60 \mathrm{ml} / \mathrm{g}$ dry tissue in untreated animals. These results indicate the presence of severe pulmonary oedema. There were no significant differences in any measured parameter between treated and untreated animals. We conclude that nebulized dexamethasone is of no value in treatment of the acute changes induced by acid aspiration.
\end{abstract}

Key Words: Complications, Acid Aspiration; Corticosteroid, nebulization.

ASPIRATION of gastric contents continues to be a major complication of general anaesthesia, particularly in the obstetrical patient.' Treatment of established acid aspiration includes tracheal suctioning, maintenance of intravascular volume, oxygenation, and mechanical ventilation with or without positive end-expiratory pressure (PEEP). ${ }^{2}$ Although the use of parenteral steroids remains controversial, they are recommended in most basic anaesthesia, ${ }^{3,4}$ medical, ${ }^{5}$ surgical, ${ }^{6}$ and obstetrical ${ }^{7}$ texts. Despite these recommendations, there is little experimental evidence indicating the value of parenteral steroids in the treatment of aspiration of acid or food and several authors ${ }^{8.9}$ have questioned the safety of parenteral steroids in patients who are at increased risk of infection.

The value of steroids administered by the

C. Brian Warriner, M.D., F.R.C.P.(C), Clinical Instructor, Department of Anaesthesia, Supported by a Research Fellowship of the British Columbia Lung Association; Louise Brooks, B.Sc., Research Assistant; Peter D. Pare, M.D., F.R.C.P.(C), Assistant Professor of Medicine, The University of British Columbia, Pulmonary Research Laboratory, St. Paul's Hospital, Vancouver, British Columbia.

Supported in part by Medical Research Council of Canada Grant MT-4219. Presented in part at the meeting of The Canadian Anaesthetists' Society at Toronto, June 1980. tracheal route is unproved. Two studies 10,11 have claimed marked improvement in animals with experimental acid aspiration treated with endotracheal steroids alone or in combination with intramuscular steroids. However, an additional study ${ }^{12}$ showed no improvement in animals with aspiration, and the development of pneumonitis in animals without aspiration suggesting a possible deleterious effect of endotracheal steroids. All three studies were uncontrolled and did not include full modern supportive therapy.

The purpose of this study was to investigate the effects of nebulized dexamethasone in dogs with acute acid aspiration who were also treated with oxygenation, mechanical ventilation, PEEP and maintenance of intravascular volume.

\section{Methods AND MATERIals}

Ten mongrel dogs (wt. 18-29 kg) were anaesthetized with pentobarbitone sodium $25 \mathrm{mg} \cdot \mathrm{kg}^{-1}$, the trachea was intubated and the lungs were ventilated with a Harvard animal respirator to maintain $\mathrm{Pa}_{\mathrm{CO}_{2}}$ at 4.25-5.32 kPa (32-40 torr). $\mathrm{FI}_{\mathrm{O}_{2}}$ was 1.0 throughout the experiment. A thermodilution Swan-Ganz catheter (Electronics for Medicine 620040) was placed in the pulmonary artery for measurement of pulmonary artery pressure (Ppa) and cardiac output (CO). Addi- 
tional catheters were placed in the left common carotid artery, pulmonary capillary wedge position and right femoral vein for measurement of systemic blood pressure (B.P.), pulmonary capillary wedge pressure (Ppaw) and for sampling of blood and injection of drugs. Transducers for measurement of vascular pressures (Statham P23BB, Hewlett-Packard X0180) were zero referenced at the bottom of the lung $(5 \mathrm{~cm}$ above the back of the animal). Pleural pressure ( $\mathrm{Ppl}$ ) was measured with an oesophageal balloon catheter (Young's Rubber Corporation, Trenton, N.J.) which was positioned in the lower one-third of the oesophagus at the point of maximum negative end expiratory pressure. The animals were positioned supine in a plexiglass volume displacement body plethysmograph and volume was measured with a Krogh spirometer coupled to a linear displacement transducer (Sanborn Lynearsyn 585 D.T.-250, Hewlett-Packard). This system has a frequency response which is flat to eight cycles/second. Transpulmonary pressure $(\mathrm{PL})$ was obtained by subtracting pleural pressure (Ppl) from tracheal pressure using a differential pressure transducer (Validyne Model M.P. 45-2). Functional residual capacity (FRC) was determined by the gas compression technique based on Boyle's law, ${ }^{13}$ residual volume (RV) was defined as the lung volume at a $\mathrm{PL}$ of $-2.94 \mathrm{kPa}$ $\left(-30 \mathrm{~cm} \mathrm{H}_{2} \mathrm{O}\right)$ and a total lung capacity (TLC) was defined as the lung volume at a $\mathrm{PL}$ of $+2.94 \mathrm{kPa}\left(+30 \mathrm{~cm} \mathrm{H}_{2} \mathrm{O}\right)$.

Control measurements of arterial and mixed venous blood gases (temperature corrected, Radiometer ABLZ Acid-Base Laboratory), vascular pressures (BP, Ppa, Ppaw), subdivisions of lung volume (TLC, VC, FRC, RV) a quasi-static deflation pressure volume curve of the lung, cardiac output, total serum proteins (American Optical T-S meter, B5996-1), haemoglobin (American Optical haemoglobinometer B4521) and haematocrit were obtained. Measurements of lung mechanics and vascular pressures were recorded on a Hewlett-Packard (7758B) eight channel recorder. After control measurements, $0.1 \mathrm{~N} \mathrm{HCl}, \mathrm{pH} 1.0$ in a dose of $15 \mathrm{ml}$ per litre of measured vital capacity was instilled down the tracheal tube and the lungs were inflated to total lung capacity. Repeat measurements were taken 20 minutes after aspiration and all dogs were placed on PEEP of $0.98 \mathrm{kPa}\left(10 \mathrm{~cm} \mathrm{H}_{2} \mathrm{O}\right)$ for the remainder of the experiment. Ringer's solution was infused at a rate to maintain cardiac output at near control levels. The dogs were randomized into two groups: treated $(N=5)$ received nebu- lized dexamethasone over two hours in a dose of $5 \mathrm{mg} \cdot \mathrm{kg}^{-1}$ by Hudson nebulizer (Updraft Neb-UMist 1700). This nebulizer produces $6 \times 10^{6}$ particles $/ \mathrm{ft}^{3}$ at $8-10 \mathrm{l} / \mathrm{min}, 75$ per cent of which are $\leq 3 \mu$ in size. Untreated animals $(N=5)$ received nebulized saline over the same time period. Repeat measurements were taken 2.5 and 5.0 hours after aspiration. Five minutes before sacrifice with intra-aortic saturated $\mathrm{KCl}$, red blood cells tagged with $100 \mathrm{u} \mathrm{Ci}{ }^{51} \mathrm{Cr}$ were injected as a marker of pulmonary blood volume to determine pulmonary extravascular water by the gravimetric technique. ${ }^{14}$ Blood samples were drawn from the pulmonary artery for later determination of haematocrit, wet-to-dry weight ratio (W/D) of blood, and radioactive counts of ${ }^{5 /} \mathrm{Cr}$ so that extravascular water could be calculated. ${ }^{14}$ After sacrifice, the chest was widely opened and multiple lung samples were taken in a systematic fashion and were then placed in pre-weighed glass scintillation vials and re-weighed to obtain wet lung weight ( $W W$ ). The amount of radioactivity of ${ }^{51} \mathrm{Cr}$ in the lung samples and systemic blood was determined using a Beckman threechannel gamma scintillation spectrometer (Model 7000). Correction was made for background radioactivity. Samples were then dried in an oven at $65^{\circ} \mathrm{C}$ until no further weight change was recorded and reweighed to obtain dry lung weight (DW). Plasma oncotic pressure was calculated from the equation of Landis and Pappenheimer ${ }^{15}$ and pulmonary capillary hydrostatic pressure (Pc) from Gaar \& Taylor, et al ${ }^{16}$ Intrapulmonary shunt (Qs/Qt) was calculated in a standard fashion. ${ }^{17}$ Static compliance was calculated from the expiratory pressure-volume curve of the lung over $500 \mathrm{ml}$ above FRC.

Unpaired t-tests were done between treated and untreated groups and paired t-tests within groups. Significance was at $p<0.05$.

\section{Calculations}

1. Calculations of lung water were based on the assumption that pulmonary artery haematocrit was representative of small vessel lung haematocrit.

Using the measurements of wet and dry ratios and ${ }^{51} \mathrm{Cr}$ counts for lung and blood samples, we calculated total lung water (TLW), blood water (BW) and pulmonary extravascular water (PEW) and expressed these parameters per gram of dry extravascular tissue (gtd).

Total Lung Water. TLW (g water/g lung) was obtained from measurements of sample wet and 
dry weights

$$
T L W=W / D-1
$$

Blood Water. BW (g blood/g lung) was obtained by dividing the number of ${ }^{51} \mathrm{Cr}$ counts/g lung by the number of ${ }^{51} \mathrm{Cr}$ counts/g systemic blood and multiplying this by the fraction of water in the blood

$\mathrm{BW}=\frac{{ }^{s} \mathrm{Cr} \text { counts } / \mathrm{g} \text { lung }}{{ }^{51} \mathrm{Cr} \text { counts } / \mathrm{g} \text { systemic blood }}$

$$
\times(1-D / W \text { blood })
$$

Exiravascular Water. PEW (g/g lung) was obtained by subtracting blood water from the total amount of lung water

$$
P E W=T L W-B W
$$

Dividing PEW/g lung by the grams of dry tissue per gram lung (gtd/g) yields PEW/gtd.

2. Calculation of Plasma Oncotic Pressure ( $\pi$ in $\mathrm{cm} \mathrm{H}_{2} \mathrm{O}$ ) is based on the following formula where $C$ represents total plasma protein concentration. ${ }^{15}$

$$
\text { plasma } \pi=\left(2.1 \mathrm{C}+0.16 \mathrm{C}^{2}+0.009 \mathrm{C}^{3}\right) 1.36
$$

3. Capillary hydrostatic pressure ( $\mathrm{Pc}$ in $\mathrm{cm}$ $\mathrm{H}_{2} \mathrm{O}$ ) is based on the following calculation: ${ }^{16}$

$$
\begin{gathered}
\text { Pc }=0.4(\text { Ppa }- \text { Ppaw })+\text { Ppaw } . \\
\text { Results }
\end{gathered}
$$

\section{Results}

The control values for all measured parameters are shown for both groups in Table I. There were no significant differences in control lung volumes, vascular pressures, weight, intrapulmonary shunt, $\mathrm{Pa}_{\mathrm{O}_{2}}$ or compliance between the two groups of dogs.

The subdivisions of lung volume (Figure 1) show that total lung capacity was reduced ( $p<$ 0.05 ) at $5.0 \mathrm{hr}$ after aspiration in both groups and at $20 \mathrm{~min}$ and $2.5 \mathrm{hr}$ after aspiration in the treated group. Residual volume was increased at 20 minutes 2.5 and 5.0 hours in the treated group, and 2.5 and 5.0 hours in the untreated group $(p<$ 0.05 ). Functional residual capacity was increased at 5.0 hours in treated and at 2.5 and 5.0 hours in untreated animals $(p<0.05$ ). Static compliance (Figure 2) was less than control at all post aspiration times in both groups $(\mathrm{p}<0.05)$. $\mathrm{Pa}_{\mathbf{O}_{2}}$ (Figure 3) was less than control $(\mathrm{p}<0.05)$ in both groups at all times after aspiration. Qs/Qt (Figure 4) increased at 20 minutes after aspiration in both

\begin{tabular}{|c|c|c|}
\hline \multicolumn{3}{|c|}{ Control MEASUREMENTS } \\
\hline Measurement & Treated $(n=5)$ & Untreated $(n=5)$ \\
\hline TLC (ml) & $2315 \pm 552$ & $2741 \pm 470$ \\
\hline $\mathrm{VC}(\mathrm{ml})$ & $2130 \pm 574$ & $2550 \pm 526$ \\
\hline FRC (ml) & $745 \pm 187$ & $776 \pm 153$ \\
\hline $\mathrm{RV}(\mathrm{ml})$ & $185 \pm 41$ & $191 \pm 85$ \\
\hline $\mathrm{CO}(1 / \mathrm{min})$ & $2.85 \pm 0.57$ & $2.69 \pm 1.1$ \\
\hline $\mathrm{Pa}_{0,}(\mathrm{kPa})$ & $73.3 \pm 6.8$ & $71.4 \pm 6.0$ \\
\hline (torr) & $(551 \pm 51)$ & $(537 \pm 45)$ \\
\hline $\mathrm{HBG}(\mathrm{g} / \mathrm{dl})$ & $12.2 \pm 1.6$ & $12.1 \pm 1.5$ \\
\hline Qs/Qt (\%) & $12.3 \pm 4.5$ & $11.0 \pm 3.8$ \\
\hline Ppa (kPa) & $1.58 \pm 0.23$ & $1.84 \pm 0.27$ \\
\hline (torr) & $(11.9 \pm 1.7)$ & $(13.8 \pm 2.0)$ \\
\hline Ppaw (kPa) & $0.78 \pm 0.47$ & $0.92 \pm 0.27$ \\
\hline (torr) & $(5.9 \pm 3.5)$ & $(6.9 \pm 2.0)$ \\
\hline$\overline{\mathrm{BP}}(\mathrm{kPa})$ & $16.76 \pm 2.26$ & $15.43 \pm 1.86$ \\
\hline (torr) & $(126 \pm 17)$ & $(116 \pm 14)$ \\
\hline $\mathrm{COMP}\left(\mathrm{ml} / \mathrm{cm} \mathrm{H}_{2} \mathrm{O}\right)$ & $117 \pm 57$ & $129 \pm 36$ \\
\hline Tot. Protein $(\mathrm{g} / \mathrm{dl})$ & $6.0 \pm 0.4$ & $6.5 \pm 0.5$ \\
\hline Weight (kg) & $21 \pm 2.8$ & $24 \pm 4.1$ \\
\hline
\end{tabular}
groups $(\mathrm{p}<0.05$ ) but returned toward control levels at 2.5 and 5.0 hours. Serum oncotic pressure did not change in either group throughout
TABLE I

Mean \pm S.D. Differences not significant.

$\mathrm{TLC}=$ total lung capacity. $\mathrm{VC}=$ vital capacity.

$F R C=$ functional residual capacity. $R V=$ residual volume.

$\mathrm{CO}=$ cardiac output. $\mathrm{Pa}_{\mathrm{O}_{2}}=$ arterial oxygen tension.

$\mathrm{HBG}=$ haemoglobin. $\mathrm{Qs} / \mathrm{Qt}=$ intrapulmonary shunt.

$\mathrm{Ppa}=$ pulmonary artery pressure. Ppaw = pulmonary capillary wedge pressure. $\overline{\mathrm{BP}}=$ mean arterial blood pressure.

COMP $=$ compliance.

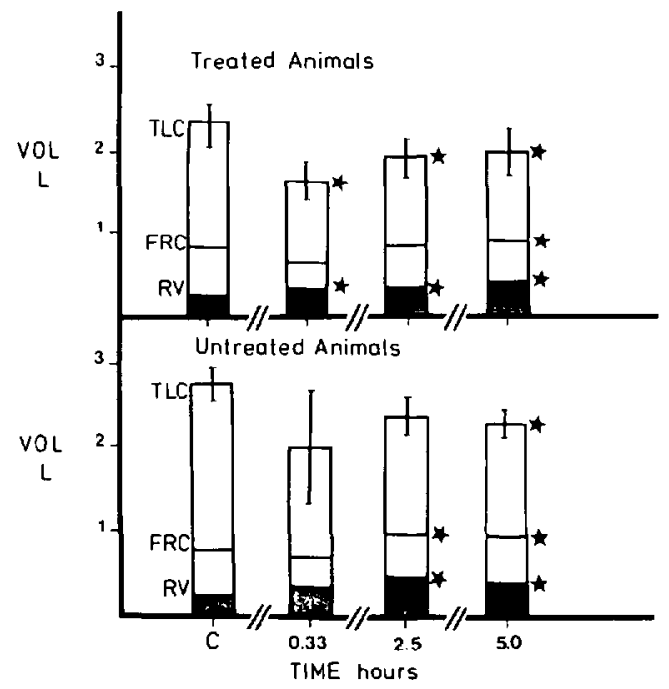

Figure 1 Subdivisions of lung volume in litres for treated and untreated animals. ${ }^{*}$ indicates significant $(p$ $<0.05$ ) change from control. TLC $=$ total lung capacity, $F R C=$ functional residual capacity, $R V=$ residual volume, $\mathrm{C}=$ control measurement. No significant difference between group. 


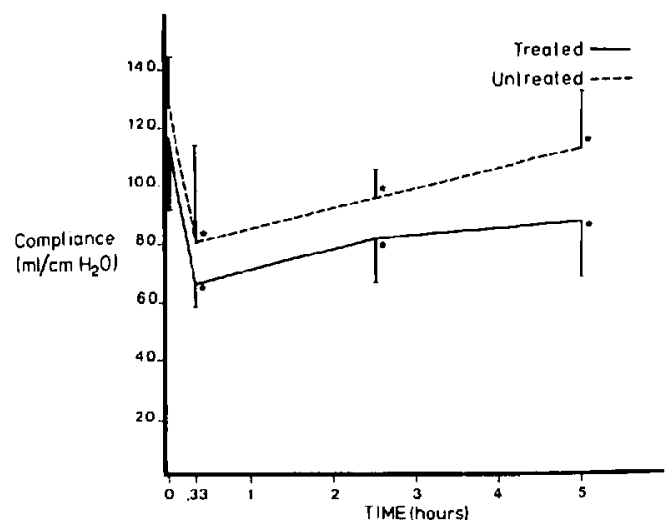

FIGURE 2 Static compliance in $\mathrm{nl} / \mathrm{cm} \mathrm{H}_{2} \mathrm{O}$ for treated and untreated animals after aspiration. ${ }^{*}$ indicates significant $(p<0.05)$ change from control. No significant difference between groups.

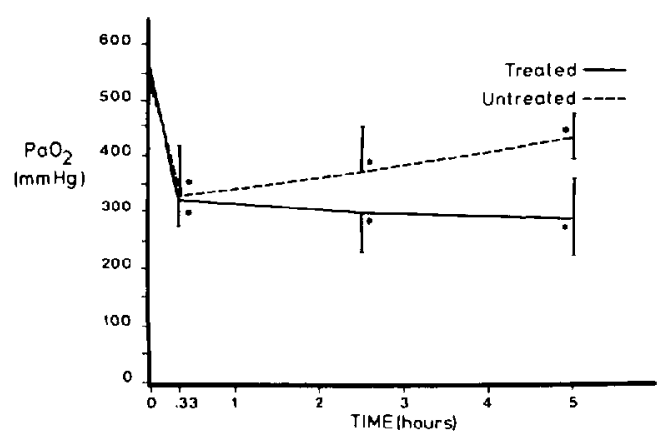

FIGURE $3 \quad \mathrm{~Pa}_{\mathrm{O}_{2}}$ in $\mathrm{mm} \mathrm{Hg}$ for treated and untreated animals after aspiration. ${ }^{*}$ indicates significant $(p<$ 0.05 ) change from control. No significant difference between groups.

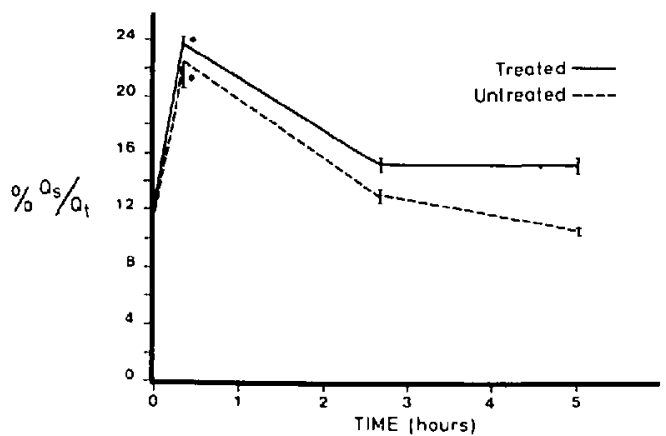

FIGURE 4 Per cent intra-pulmonary shunt for treated and untreated animals after aspiration. ${ }^{*}$ indicates significant $(p<0.05)$ change from control. No significant difference between groups.

the experiment and pulmonary capillary hydrostatic pressure was significantly increased in both groups at 5.0 hours after aspiration (Figure 5). Pulmonary extravascular water (Table II) was $6.16 \pm 0.93 \mathrm{ml} / \mathrm{g}$ dry tissue in treated animals and

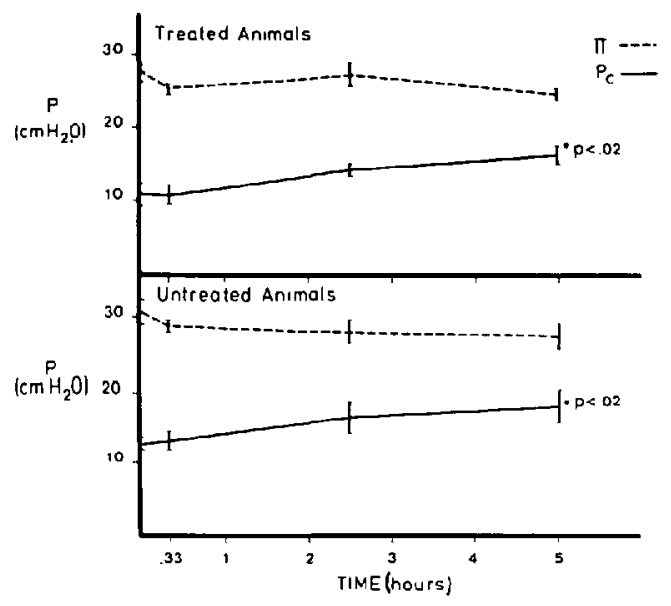

Figure 5 Plasma oncotic pressure $(\mathrm{P} \pi)$ and pulmonary capillary hydrostatic pressure $(\mathrm{Pc})$ for treated and untreated animals after aspiration. * indicates significant $(p<0.02)$ change from control. No significant difference between groups.

$6.47 \pm 0.60 \mathrm{ml} / \mathrm{g}$ dry tissue in untreated animals (mean $\pm \mathrm{SD}$ ). PEW in normal ventilated dogs in this laboratory is $3.41 \pm 0.16 \mathrm{ml} / \mathrm{g}$ dry tissue. Our measurements indicate marked pulmonary oedema.

There were no significant differences in the changes in lung mechanics, gas exchange or lung water between treated and untreated dogs.

\section{Discussion}

In the present experiment we studied the effects of acute aspiration of $0.1 \mathrm{~N} \mathrm{HCl}$ with a $\mathrm{pH}$ of 1.0 on lung volumes and mechanics, gas exchange and haemodynamics in dogs. We also studied possible modification of these acute effects by high dose nebulized dexamethasone.

Our animals developed marked pulmonary oedema as indicated by pulmonary extravascular water values that are nearly twice normal. Gas exchange as measured by $\mathrm{Pa}_{\mathrm{O}_{2}}$ and $\mathrm{Qs} / \mathrm{Qt}$ was markedly impaired within 20 minutes of aspira-

TABLE II

Pulmonary Extravascular WATER/G DRY TISSUE

\begin{tabular}{ll}
\hline \hline Treated & Untreated \\
\hline 6.39 & 5.90 \\
5.64 & 6.36 \\
6.70 & 7.00 \\
4.84 & 7.07 \\
7.22 & 6.31 \\
\hline $6.16 \pm 0.93$ & $\overline{6.47} \pm 0.60$ \\
\hline \multicolumn{2}{l}{ (Mean \pm S.D.) }
\end{tabular}


tion and lung volumes were decreased. These results can all be explained by the development of severe alveolar oedema following acid aspiration.

In this study acid was injected as a bolus, rather than nebulized, as this is the situation clinically. The steroid was nebulized in an effort to distribute the drug to all areas of the lung because an intratracheal bolus of dexamethasone would be distributed in a patchy, unpredictable manner with no guarantee that the agent would reach the sites of acid damage. Nebulization of the dexamethasone does not guarantee even distribution of the drug as areas of atelectasis uncorrected by PEEP would receive little of the agent. Delivery by nebulization, however, will ensure the best possible distribution of agents administered through the airway. If any value could be shown from inhalational steroid, it would be an easy matter to add it to the treatment regimen of patients being ventilated after aspiration.

We concentrated on the acute changes produced by acid aspiration and our results show that there are marked changes in lung volumes, gas exchange, and intrapulmonary shunt within 20 minutes of acid aspiration. While there is some improvement in shunt and lung volumes following treatment with oxygen, ventilation, and PEEP, the improvement is no greater in animals receiving nebulized dexamethasone than in those receiving nebulized saline. Chapman and Modell, ${ }^{20}$ using aspirate volumes similar to ours, had mortalities of 68 per cent in the first 24 hours after aspiration in spontaneously breathing dogs. When controlled positive pressure ventilation was added to the treatment regimen, ${ }^{21}$ mortality dropped to 40 per cent in the first 24 hours. This high early mortality leads us to believe that any treatment advocated for acid aspiration must show early improvement in the animals. Our results fail to show any improvement in the acute outcome of acid aspiration with the use of nebulized dexamethasone.

Aspiration of acidic gastric contents produces a patchy chemical burn immediately, with the development of epithelial degeneration of the bronchi, pulmonary oedema, and haemorrhage within the first few hours. ${ }^{2}$ The role of steroids in the treatment of acid aspiration remains controversial. Advocates contend that steroids should improve outcome by reducing inflammation, stabilizing lysosomal membranes, preventing platelet and leukocyte agglutination and increasing oxygen delivery to tissues by shifting the oxyhaemoglobin dissociation curve to the right. ${ }^{2}$
Despite these theoretical considerations experimental support is lacking. The value of parenteral steroids has been investigated by Lawson, et $a .^{18}$ who were unable to show any differences in mortality or pathology in treated animals. Chapman, Modell, et al, in three well-controlled studies ${ }^{19-21}$ were unable to show any differences in outcome of acid aspiration between dogs recciving no steroids, single high-dose steroids, multiple high-dose steroids, or multiple low-dose steroids. In the ex vivo lung, however, Toung, Bardos, Benson, et al. ${ }^{22}$ were able to show that the addition of high doses of methylprednisolone to the perfusate five minutes after aspiration was associated with less increase in lung weight and improved lung inflation.

The failure of parenteral steroids to improve the outcome of acid aspiration in vivo might be due to failure of the drug to reach the site of injury in amounts sufficient to modify tissue damage. Is there any value in applying the steroid directly to the injured tissue? The use of intratracheal steroids has been reported in three previous studies. ${ }^{10-12}$ In the first of these, ${ }^{10}$ Lewinski compared a number of methods of treating aspiration of $10 \mathrm{ml} 0.1 \mathrm{~N} \mathrm{HCl}$ in cats. The instillation of $25-50 \mathrm{ml}$ of hydrocortisone solution in $10 \mathrm{ml}$ $\mathrm{NaHCO}_{3}$ down the tracheal tube was associated with a low incidence of necrosis and oedema compared to groups of animals not given this solution. No attempt was made to show any statistically significant differences between treatment groups.

A second study" by Wamberg and Zeskov compared a number of modalities in the treatment of acid ( $15 \mathrm{ml} 0.1 \mathrm{~N} \mathrm{HCl}$ ) aspiration in cats. They found improved survival and resolution of pneumonia in cats receiving intratracheal Solvisat Leo (hydrocortisone xanthogen acidum) plus daily intramuscular injections of cortisone. Again, no statistical evaluation of results was attempted.

In the study by Taylor and Pryse-Davies, ${ }^{12}$ rabbits and cats were given $\mathrm{HCl}$ various $\mathrm{pH}$ followed by various treatments. There was no apparent useful effect from intratracheal hydrocortisone although numbers were small and no statistical analysis was done. A group of normal cats given intratracheal hydrocortisone developed pneumonitis suggesting that steroids damaged the lungs. In our study we could show no value in the use of nebulized dexamethasone in the treatment of acute acid aspiration.

In summary, acute acid aspiration produces marked changes in lung mechanics, gas exchange and intrapulmonary shunt. These changes are 
alleviated to some degree by oxygenation, mechanical ventilation with PEEP and intravascular volume replacement. There is no beneficial effect of nebulized dexamethasone on the acute changes of the acid aspiration syndrome in dogs.

\section{REFERENCES}

1. COHEN, S.E. Aspiration syndromes in pregnancy. Editorial. Anesthesiology 51:375-377 (1979).

2. WYNNE, J.W. \& MODELL, J.H. Respiratory aspiration of stomach contents. Ann. Intern. Med. 87: 466-474 (1977).

3. Schnider, S.M. \& Levinson, G. Anesthesia for Obstetrics. Baltimore, Williams and Wilkins (1979).

4. Wylie, W.D. \& ChURChILl-Davidson, H.C. Editors: A Practice of Anesthesia. 4th Edition. Chicago, Year Book Medical Publications (1979).

5. Thorn, G.W., Adams, R.D, Braunwald, E., et al., eds. Harrison's Principles of Internal Medicine. 8th Edition. New York, McGraw-Hill Book Company (1977).

6. SchwarTZ, S.I. Editor. Principles of Surgery. 3rd Edition. New York, McGraw-Hill Book Company (1979).

7. Pritchard, J.A. \& Macdonald, P.C. Williams Obstetrics. New York, Appleton-Century-Crofts (1976).

8. WYNNE, J.W., REYNOLDS, J.C., Hood, C.I., et al. Steroid therapy for pneumonitis induced in rabbits by aspiration of foodstuffs. Anesthesiology 51 : 11-19(1979)

9. WOLFE, J.E., Bone, R.C. \& Ruth, W.E. Effects of corticosteroids in the treatment of patients with gastric aspiration. Am. J. Med. 63: 719-722 (1977).

10. LEwINSKI, A. Evaluation of methods employed in the treatment of the chemical pneumonitis of aspiration. Anesthesiology 26(1): 37-44 (1965).

11. WAMBERG, K. \& ZesKov, B. Experimental studies on the course and treatment of aspiration pneumonia. Anesth. Analg, 46(2): 230-236 (1966).
12. Taylor, G. \& Pryse-Davies, J. Evaluation of endotracheal steroid therapy in acid pulmonary aspiration syndrome (Mendelson's Syndrome). Anesthesiology 29(1): 17-21 (1968).

13. MEAD, J. Volume displacement body plethysmograph for respiratory measurement in human subjects. J. Appl. Physiol. 15: 736-740 (1960).

14. Baile, E.M., Pare, P.D., Dahlay, R.W., et al. Regional distribution of extravascular water and hematocrit in the lung. J. Appl. Physiol. 46(5): 937-942 (1979).

15. Landis, E.M. \& Pappenheimer, J.R. Exchange of substances through the capillary walls. Handbook of Physiology. Circulation. Washington D.C., American Physiological Society, sec. 2, vol. 2, ch. 29, pp 961-1034 (1963).

16. GaAr, K.A. JR., TAYlor, A.E., OWens, L.J., et al. Pulmonary capillary pressure and filtration coefficient in the isolated perfused lung. Am. J. Physiol. 213: 910-914 (1967).

17. West, J.B. Respiratory Physiology - The Essentials. Baltimore, Williams and Wilkins (1974).

18. Lawson, D.W., Defalco, A.J. \& Pheles, J.A. Corticosteroids as treatment for aspiration of gastric contents: An experimental study. Surgery 59: 845-852 (1966).

19. Chapman, R.L., Modell, J.H., Ruiz, B.C., et al. Effect of continuous positive pressure ventilation and steroids on aspiration of hydrochloric acid $(\mathrm{pH}$ 1.8 ) in dogs. Anesth. Analg. (Cleve.) 53: 556-562 (1974).

20. Downs, J.B., Chapman, R.L., Modell, J.H., et al. An evaluation of steroid therapy in aspiration pneumonitis. Anesthesiology 40(2): 129-135 (1974).

21. Chapman, R.L., Downs, J.B., Modell, J.H., et al. The ineffectiveness of steroid therapy in treating aspiration of hydrochloric acid. Arch. Surg. 108: 858-86I (1974).

22. Toung, T.J.K., Bardos, D., Benson, D.W. CARTer, D., Zuidema, Y.G., Permutt, S. \& CAmeron, J.L. Aspiration pneumonia: Experimental evaluation of albumin and steroid therapy. Ann. Surg. 183(2): 179-184 (1976).

RÉSUMÉ

Les effets d'une aspiration de liquide acide ainsi que les modifications de ses effets par un traitement à la dexaméthazone, en nébulisation, ont fait l'objet d'une étude chez le chien. Les modifications étudiées étaient celles de la mécanique et de l'hémodynamique pulmonaire, ainsi que celles des échanges gazeux et de l'eau pulmonaire extra-vasculaire. A cet effet, on instillait dans le tube trachéal de chacun des animaux $15 \mathrm{ml} / \mathrm{l}$ de capacité vitale d'une solution $0.1 \mathrm{~N}$ d'acide chlorhydrique. Une PEEP de $10 \mathrm{~cm} \mathrm{H}_{2} \mathrm{O}$ était initiée vingt minutes après l'aspiration. Chez cinq des animaux on commençait également la nébulisation de dexaméthazone $\left(5 \mathrm{mg} \cdot \mathrm{kg}^{-1}\right)$ vingt minutes après l'aspiration. Cette nébulisation s'étendait sur une période de deux heures. Cinq autres animaux (groupe témoin) recevaient du soluté physiologique en nébulisation. Les mesures étaient effectuées avant l'aspiration, puis vingt minutes, deux heures et demie et, enfin, cinq heures après l'aspiration. On injectait des globules rouges marqués au $\mathrm{Cr}^{51}$ avant de sacrifier les animaux. Des échantillons pulmonaires multiples étaient prélevés après le sacrifice pour la mesure de l'eau pulmonaire extravasculaire (technique gravimétrique).

L'aspiration de liquide acide causait des modifications significatives des volumes pulmonaires, de la $\mathrm{Pa}_{\mathrm{O}_{2}}$ et du shunt. L'eau pulmonaire extravasculaire était de $6.16 \pm 0.93$ $\mathrm{ml} / \mathrm{g}$ de tissu sec chez les animaux traités et de $6.47 \pm 0.6 \mathrm{ml} / \mathrm{g}$ chez les animaux non traités. Ces résultats témoignent d'un œdème pulmonaire important. On n'a pas trouvé de différence significative dans les paramètres mesurés entre les animaux traités et non traités. Nous concluons que le dézaméthazone en nébulisation est sans valeur dans le traitement des modifications aigues causées par une aspiration de liquide acide. 